\title{
Experimental investigation on flexural performance of functionally graded concrete beams using flyash and red mud
}

\author{
Investigação experimental sobre o desempenho \\ flexural de vigas de concreto funcionalmente \\ classificadas usando flyash e lama vermelha
}

Sureshkumar Muthu Palaniappan ${ }^{1}$, Vennila Govindasamy ${ }^{2}$, Abdul Bari Jabar ${ }^{3}$

\footnotetext{
${ }^{1}$ Assistant Professor, Department of Civil Engineering, K.S.Rangasamy College of Technology, K. S. R Kalvi Nagar, Tiruchengode, Tamilnadu, India - 637215.

${ }^{2}$ Professor, Department of Civil Engineering, K.S.Rangasamy College of Technology, K. S. R Kalvi Nagar, Tiruchengode, Tamilnadu, India - 637215.

${ }^{3}$ Assistant Professor, Department of Civil Engineering, K.S.Rangasamy College of Technology, K. S. R Kalvi Nagar, Tiruchengode, Tamilnadu, India - 637215.

e-mail: sureshkumarmp@gmail.com, vennilajagan@gmail.com, ursabdul@gmail.com
}

\begin{abstract}
The continuous change in the strength and other properties, environmental problems, hike in cement price, advancement of construction industry makes the usage of alternative materials as Functionally graded materials (FGM) which leads to a new materials on concrete as Functionally graded concrete (FGC), In this present paper, investigation has carried out on the functionally graded concrete by using red mud and also fly ash. In this $\mathbf{M}_{20}$ grade of concrete is used as the conventional concrete in compression zone and $\mathrm{M}_{25}$ with the replacement of cement by red mud and flyash with varying percentage $(5 \%, 10 \% 15 \%)$ respectively in the tension zone. The results indicated that the $10 \%$ of the red mud and $10 \%$ of the fly ash as the optimum value for the concrete beam and by load deflection curve, it is evident that functionally graded concrete beam has more advantages than ordinary concrete since it has more durability and strength characteristics. Scanning electron microscope analysis was also carried out on the red mud functionally graded concrete and fly ash functionally graded concrete. It clearly indicated the pores present in the materials which tends to increase in strength of the concrete.
\end{abstract}

Keywords: Functionally graded concrete, $\mathrm{M}_{20}$ and $\mathrm{M}_{25}$ grade, Scanning electron microscope, Red mud, Flyash.

\section{RESUMO}

A mudanca contínua na forca e outras propriedades, problemas ambientais, aumento no preco do cimento, avanco da indústria da construção civil faz uso de materiais alternativos como materiais de grau funcional (FGM) que leva a um novo material sobre concreto como concreto funcionalmente classificado (FGC), Neste presente artigo, a investigação tem sido realizada no concreto funcionalmente classificado utilizando lama vermelha e também sobre cinzas.Neste grau M20 de concreto é usado como concreto convencional na zona de compressao e M25 com a substituicao de cimento por lama vermelha e flyash com porcentagem variada $(5 \%, 10 \%, 15 \%)$ respectivamente na zona de tensao. Os resultados indicaram que os $10 \%$ da lama vermelha e $10 \%$ das cinzas de mosca como o valor ideal para o feixe de concreto e pela curva de deflexao de carga, e evidente que o feixe de concreto funcionalmente classificado tem mais vantagens do que o concreto comum, uma vez que possui mais durabilidade e características de resistencia.A análise do microscopio eletronico de varredura também foi realizada no concreto de grau funcional da lama vermelha e cinzas de moscas de con- 
creto funcionalmente classificado.Indicou claramente os poros presentes nos materiais que tendem a aumentar a forca do concreto.

Palavras-chave: Concreto funcionalmente classificado, grau M20 e M25, microscópio eletrônico de varredura, lama vermelha, Flyash.

\section{INTRODUCTION}

The construction field mainly utilizes the concrete in almost all parts of the world. The conventional or ordinary Portland cement concrete is popularly known is used due to its various advantages as high compressive strength or its low cost. Because of the technical and environmental aspects concrete has some disadvantages. Over the past decades, functionally graded materials (FGM) have been increasing rapidly since their potential in cost optimizations and enhancement in materials performance HAN AYLIE et al. [13]. FGM is combination of two or more materials with different essential properties KOIZUMI [15]. The concept of the functionally graded materials is the basic for the development of Functionally Graded Concrete (FGC) Satyanarayana et al. [14]. Various investigations have been carried out on the FGC. Numerous mechanical problems obtained during optimization of the mechanical properties, which includes determinations of the properties and the crack propagation behaviour Bafekrpour et al. [16]. Functionally graded materials are prepared using sulphur concrete with the changes in the thickness by varying the rubber. These changes results FGM could be optimized Mohammadi et al. [18]. Functionally graded concrete materials (FGCMs) would be constructed in multiple layers by incrementally varying the material properties. FGM may also increase the residual stress distribution, thermal resistance, and resistance to cracking and reduce the stress intensity factor, so it is a very promising material that requires research for further developments. The load carrying capacity of FGC flexural beams was investigated by means of finite element mode. A combination of two different concrete strengths shows significant changes in the stiffness and ultimate load of the FGC beams HAN AYLIE et al. [13]. As the concrete is weak in its tensile strength, so it is economical to use functionally graded beam (FGB). The weakness of concrete such as shrinkage during coagulation and hardening, low tensile strength, poor crack resistance, brittleness, small ultimate extension and bad impact endurance, which prevails in concrete and limits its application, has been thoroughly dealt with in FGB SATYANARAYANA et al. [14]. Various works have been proved that the durability of the functionally graded concrete has been improved over regular concrete LIQINGHUA et al. [17]. Experimental and numerical investigations on the effects of two concrete strength gradation of FGC cylinder compressive strength have reported the high compressive strength of the FGC mixture HAN AYLIE et al. [13]. Although FGM was initially developed using metal material for spacecraft applications, nowadays it is also studied for building elements such as beams, plates, and shells. Figure. 1 shows the graphical representation of cross section of functionally graded concrete specimen.

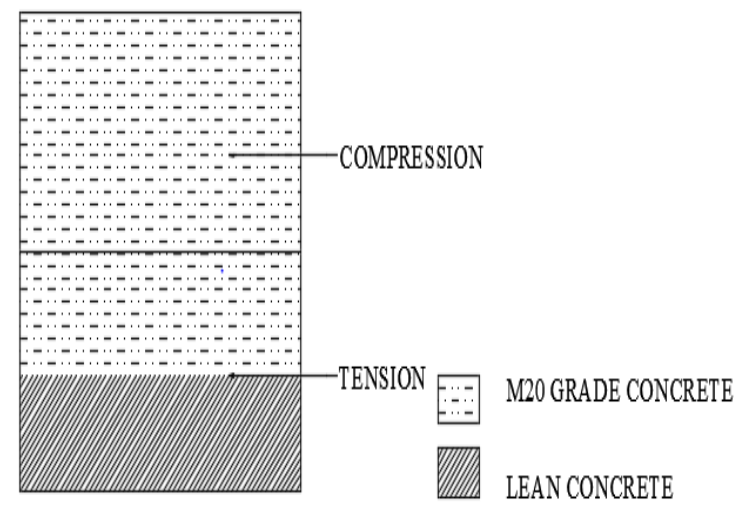


Figure 1:. Graphical representation of Functionally Graded Concrete Specimen

As the functionally graded materials have an application in aerospace, infrastructure and other engineering applications. Fly ash enhances the workability, compressive and flexural strength due to hike in cement. Hence the functionally graded concrete makes it more economical than ordinary concrete. Fly ash, Red mud, Fibre reinforced concrete, natural fibres are some of the sources of functionally graded concrete. In this present investigation fly ash and red mud has used.

The inorganic waste generated during the process of extraction of the alumina from bauxite is RED MUD SMITA SINGH et al. [19]. Generally red mud is based on the reaction of bauxite with sodium hydroxide under high temperature and pressure BRUNORI et al. [20]. During the production of 1 ton of alumina results on 1.5 to 1.6 tons of red mud. Around $95 \%$ of the alumina produced all over the world is the bauxite extraction by Bayer Process.

As per International aluminium institute, Bauxite is classified as Gibbsitic, Diasporic or Boehmitic with varying compositions. Bauxite are mined in countries like Australia, Brazil, India, Greece, Guyana, etc DENTONI et al. [3]. Table 1 shows the production of the red mud in some countries.

Table 1: Production of Red Mud

\begin{tabular}{c|l|c|c}
\hline S.No & Country & Annual Production of Red Mud in million tons & \multicolumn{1}{c}{ Reference } \\
\hline 1 & Australia & 30 & Sutar et al, 2014 \\
\hline 2 & Brazil & 10.6 & Lima et al, 2017 \\
\hline 3 & India & 10 & Vijaya et al, 2018 \\
\hline 4 & Greece & 0.7 & Sutar et a, l 2014 \\
\hline
\end{tabular}

Several research works has carried out on incorporating red mud by disposing in the cost effective way HOODA et al. [5] in the construction industry as the cement, Ceramics YANG et al [6], lightweight aggregate MOLINEUX et al. [4]. Another product used in the functionally graded concrete is the fly ash which is a solid, fine grained material resulting burning of pulverized coal in power station furnaces. For a sustainable development of the concrete industry High volume fly ash concrete is used which typically have 50-60\% of fly ash content YANG et al. [6]. The usage of fly ash has in concrete has advantages like reduction of water demand, improves the workability, minimize the crack pattern and enhance durability to reinforcement corrosion Yang et al. [6]. Researchers found usage of fly ash in concrete has significantly increased in compressive strength. The contribution of the fly ash in the concrete mixes prepared at low w/c ratio was greater than mixed at high w/c ratio LAM et al. [10]. The strength of the concrete containing fly ash is more sensitive for poor curing than the control concrete RAMEZANIANPOUR et al. [12]

The focus of this present investigation is to investigate the behaviour of the functionally graded concrete for the desired mixed of $\mathrm{M}_{20}$ and $\mathrm{M}_{25}$. Cement is replaced with the red mud with the varying percentages of $5 \%, 10 \%$ and $15 \%$ and similarly with the replacement of fly ash as 5\%,10\%, 15\% respectively. The compressive strength, tensile strength and the load carrying capacity of the concrete beam is also determined for the FGC specimens and the cross section of the FGC for the red mud and the fly ash is observed using scanning electron microscope (SEM). Two point loading were carried out to observe the bending behaviour of the specimens.

\section{EXPERIMENTAL WORK}

\subsection{Materials}

The main components of the FGC were ordinary Portland cement, Fine aggregate, Coarse aggregate, Fly ash and Red mud. In this Cement, Fine Aggregate and Coarse aggregate are commonly used materials in construction industry. The Ordinary Portland cement of 53 grade is used confirming to IS 12269:1987 with con- 
form to American Society for Testing and Materials (ASTM) Classification as C150 (Type I) Cement with the specific gravity of the cement as 3.15. The fine aggregate used are obtained from the natural river with the specific gravity of 2.67 and the coarse aggregate of $20 \mathrm{~mm}$ size of 2.78 specific gravity is used which is a hard blue granite stones from quarries.

\subsection{Fly Ash:}

The by-product of the crushed coal which is widely used as a cementitious and pozzolanic ingredient in concrete is the fly ash. Fly ash has cementitious property due to which it enhances the workability, compressive strength and flexural strength. Fly ash used in this work collected from the Mettur Thermal Power station, India.

\subsection{Red Mud:}

The by-product generated from the alumina refining process is the red mud which is a Bauxite residue obtained on the reaction of bauxite with sodium hydroxide at high temperature, BRUNORI, et al. 2005 [20]. The waste generated from the alumina refining industry has more alkalinity and causes significant environmental pollution. To solve these issues is to develop the economic utilization technologies that consume some amount of red mud. The key areas for utilization of the red mud are making of ceramics, bricks, and raw materials for cement and road materials. Hence in this investigation red mud is used with varying percentage in the functionally graded concrete. The red mud used in this work is obtained from Malco (Madras Aluminium Company Limited), India. The major components of the red mud generated is given in Table 2

Table 2: Major Components of red mud generated in alumina plant

\begin{tabular}{c|c|c|c|c|c}
\hline \multicolumn{7}{c}{ Major Components (Wt. \%) } \\
\hline $\mathrm{Al}_{2} \mathrm{O}_{3}$ & $\mathrm{Fe}_{2} \mathrm{O}_{3}$ & $\mathrm{SiO}_{2}$ & $\mathrm{TiO}_{2}$ & $\mathrm{Na}_{2} \mathrm{O}$ & $\mathrm{CaO}$ \\
\hline 21 & 42 & 13 & 1.8 & 4.3 & 1.2 \\
\hline
\end{tabular}

The properties of the fly ash and the red mud used in this investigation are given in Table 3 and Table 4

Table 3: Properties of Fly ash and Red Mud

\begin{tabular}{c|c|c|c}
\hline Material & Specific Gravity & Surface Area $\left(\mathbf{m}^{2} / \mathbf{k g}\right)$ & $\mathbf{p H}$ \\
\hline Red mud & 2.5 & 33650 & 12 \\
\hline Fly Ash & 2.27 & 220 & 7.6 \\
\hline
\end{tabular}

Table 4: Chemical Composition of Red mud and Fly ash

\begin{tabular}{c|c|c}
\hline Determination & Red mud & Fly ash \\
\hline $\mathrm{SiO}_{2}$ & 16.2 & 54.5 \\
\hline $\mathrm{Fe}_{2} \mathrm{O}_{3}$ & 36.1 & 6.0 \\
\hline $\mathrm{CaO}$ & 1.0 & 6.5 \\
\hline $\mathrm{Al}_{2} \mathrm{O}_{3}$ & 21.3 & 23.2 \\
\hline
\end{tabular}

\section{EXPERIMENTAL METHODS}

In this investigation the compressive strength of the functionally graded concrete cubes is studied at 28 days with the placing of red mud and fly ash respectively at the distance of $25 \mathrm{~mm}, 50 \mathrm{~mm}$ and $75 \mathrm{~mm}$ from the bottom of the concrete cubes with the remaining $125 \mathrm{~mm}, 100 \mathrm{~mm}$ and $75 \mathrm{~mm}$ are the conventional concrete with the grades of the concrete used as $\mathrm{M}_{20}$ and $\mathrm{M}_{25}$ respectively. Also the flexural strength of the FGC specimen is determined at 28 days with the replacement of cement at 5\%,10\% and $15 \%$ of Fly ash with both $\mathrm{M}_{20}$ and $\mathrm{M}_{25}$ grade concrete. To determine the deflection concrete beam is cast with the dimension of $1100 \mathrm{~mm} \mathrm{x}$ $100 \mathrm{~mm} \times 150 \mathrm{~mm}$ under two point loading conditions. The reinforcement details of the beam is shown in the 
Figure.2 The microstructural characterizations of the specimens are also found out using Scanning Electron Microscope (SEM).
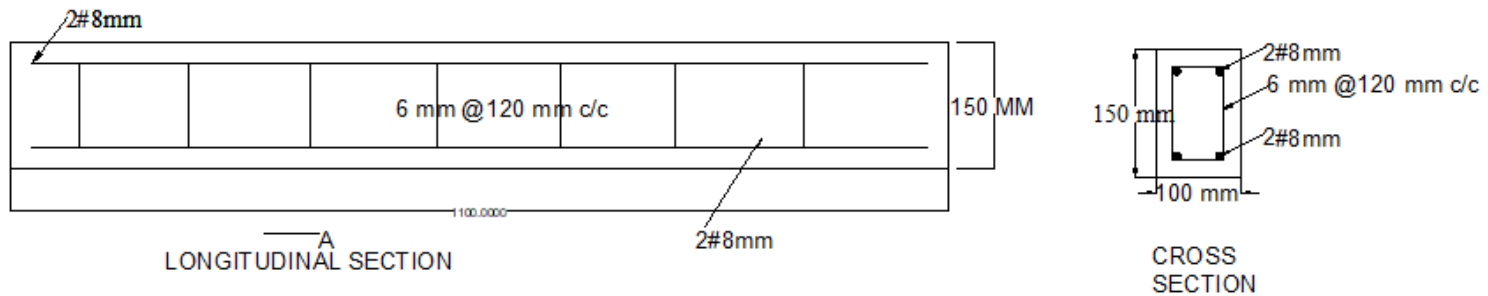

Figure 2: Reinforcement details of Beam

\subsection{Mix Design:}

The mix design adopted in this study is based on IS codal Provison (IS: 10262-2009). The mix proportion for $\mathrm{M}_{20}$ and $\mathrm{M}_{25}$ is shown in Table 5

Table 5: Mix Details used in the functionally graded concrete

\begin{tabular}{c|c|c|c|c}
\hline Mix Code & Cement $\left(\mathbf{k g} / \mathbf{m}^{\mathbf{3}}\right)$ & Fine Aggregate $\left.\mathbf{( k g} / \mathbf{m}^{\mathbf{3}}\right)$ & Coarse Aggregate $\left.\mathbf{( k g} / \mathbf{m}^{\mathbf{3}}\right)$ & Water $\left(\mathbf{k g} / \mathbf{m}^{\mathbf{3}}\right)$ \\
\hline $\mathrm{M}_{20}$ & 394 & 692.46 & 1127.70 & 197 \\
\hline $\mathrm{M}_{25}$ & 437.7 & 724 & 1130.35 & 197 \\
\hline
\end{tabular}

\section{RESULTS AND DISCUSSION}

\subsection{Compressive Strength}

The Compression strength test according to IS:516 - 1959 at ages of 28 days on the cube specimen of standard size $150 \mathrm{~mm}$ were used which represent the average of the three number of cube specimens. The result of the compressive strength of red mud and fly ash of the respective percentage variations (5\%, 10\% and $15 \%)$ is shown in Fig 3 and Fig 4.

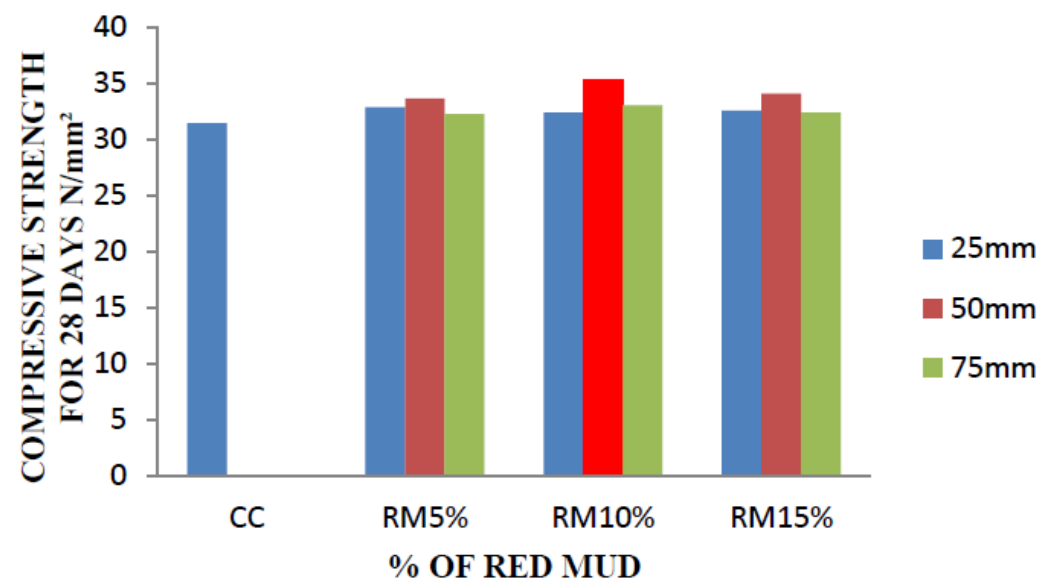

Figure 3: Compressive strength of Red Mud 


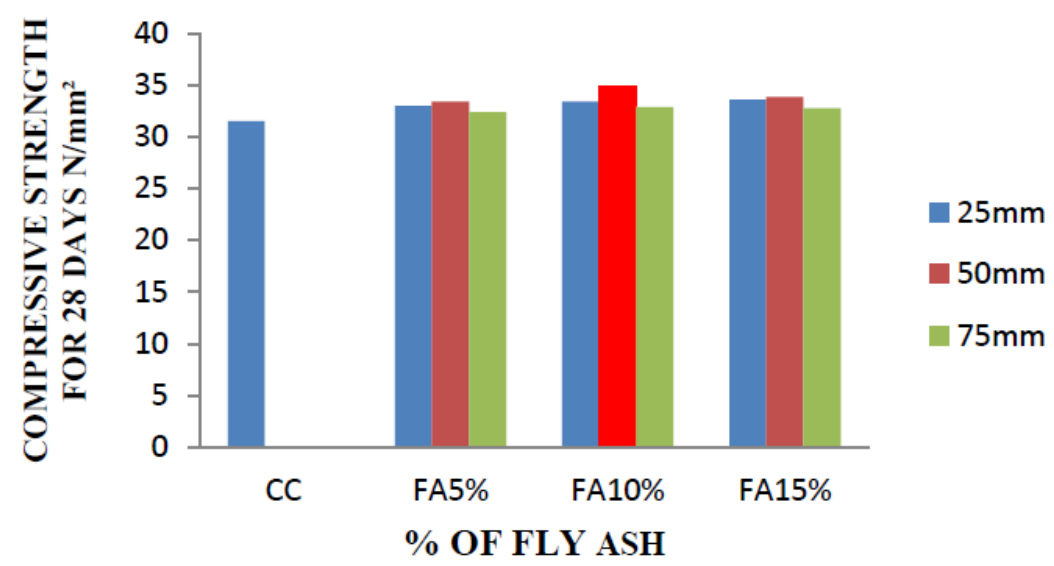

Figure 4: Compressive strength of Fly ash

\subsection{Flexural Behaviour of Specimen}

The beam specimen of size $1100 \mathrm{~mm}$ long, $100 \mathrm{~mm}$ wide and $150 \mathrm{~mm}$ deep is tested under two point loading condition in the loading frame as shown in the Fig 5. A load cell of $500 \mathrm{kN}$ is used to find the applied load. Deflections were measured in the mid span of the beam using LVDT.

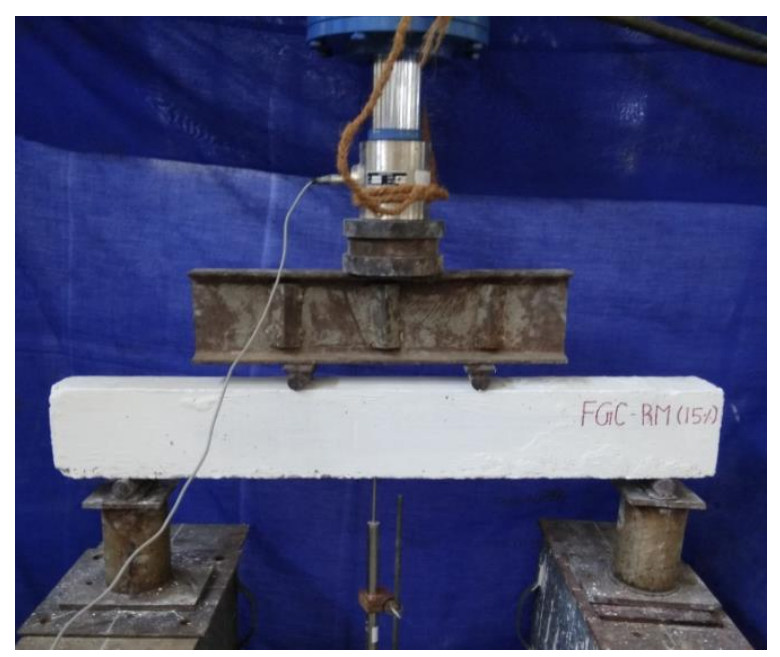

Figure 5: Experimental Set up

The first crack load of the control specimen is observed as 20.3, where as for the functionally graded concrete of red mud 5\%,10\% and $15 \%$ is observed as $21.6 \mathrm{kN}, 23.4 \mathrm{kN}$ and $16.3 \mathrm{kN}$ respectively. Similarly for the functionally graded concrete of Fly ash for $5 \%, 10 \%$ and $15 \%$ is observed as $20.7 \mathrm{kN}, 22.2 \mathrm{kN}$ and $18.1 \mathrm{kN}$ as shown in Fig.6 


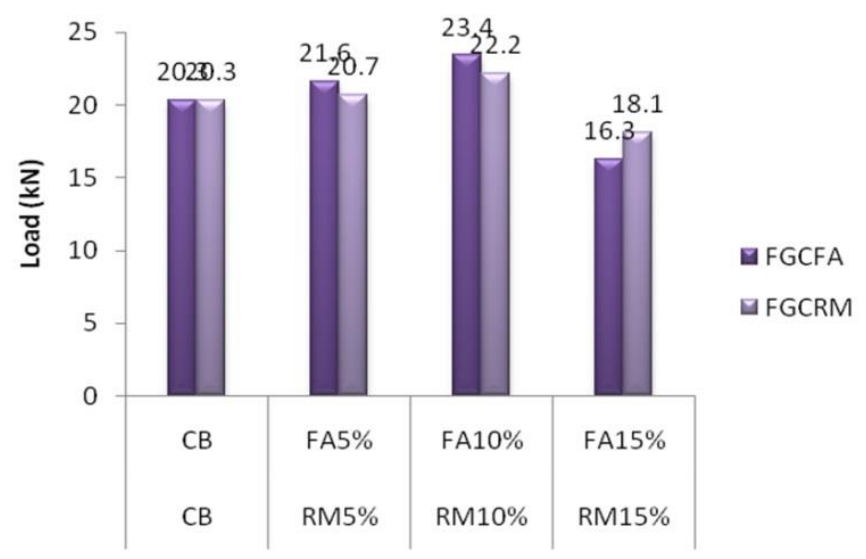

Figure 6: First Crack Load

The load- deflection behaviour of the control beam and functionally graded concrete beam is observed in figure 7(FGC, Flyash) and figure 8 (FGC, Red Mud) through load-deflection behaviour. At the mid-span of the beam the deflection is measured. From the plot it has been observed that deflection behaviour of functionally graded concrete beam of the red mud and fly ash was higher than the conventional beam.

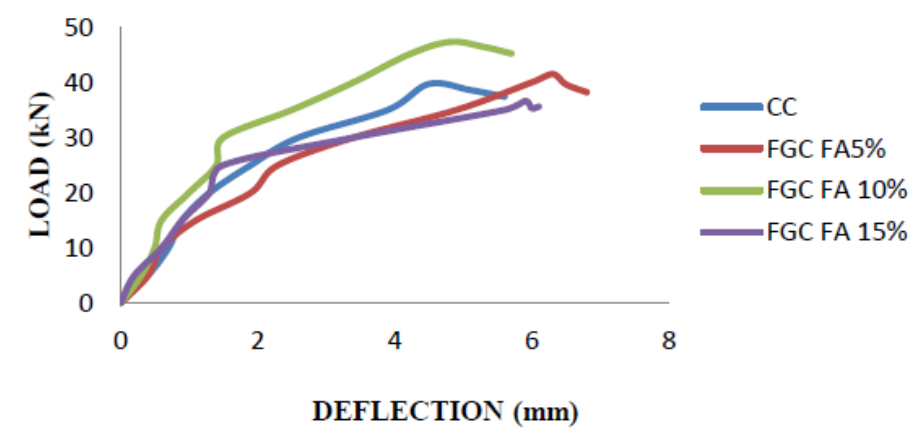

Figure 7: Load -Deflection behaviour of Control beam and functionally graded Concrete Fly ash beam

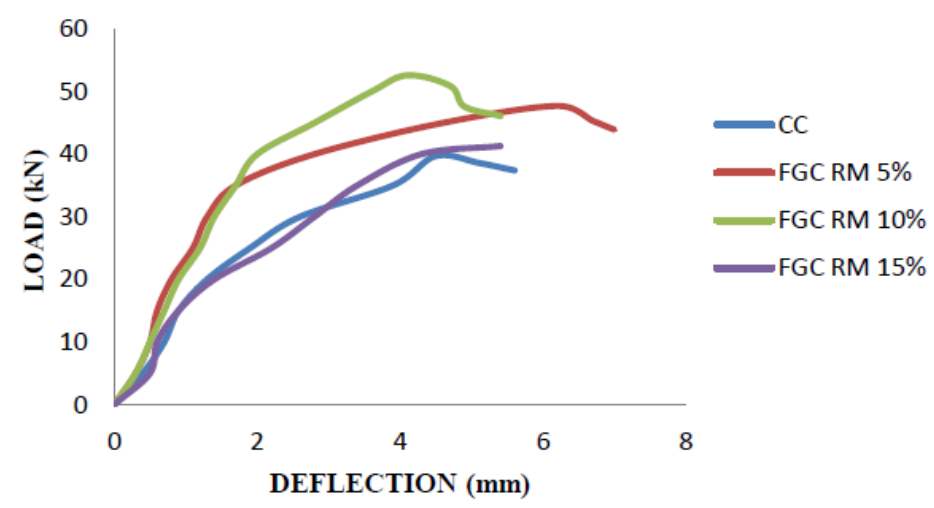

Figure 8: Load -Deflection behaviour of Control beam and functionally graded Concrete Red Mud beam

\subsection{Ductility Factor}

Ductility is one of the most important parameters to be considered in the design of structure subjected to large amount of inelastic deformation due to various loading conditions such as wind, seismic or impact load- 
ing. It is defined as the ability of a member to undergo inelastic deformations beyond the yield deformation without significant loss in its load carrying capacity. The ductility of a flexural member can be obtained from its load-deflectioncurve. The ratio of ultimate deflection at first yield is known as ductility factor $(\mu)$. The Figure 9 and Figure 10 showed the ductile behaviour of the beam member.

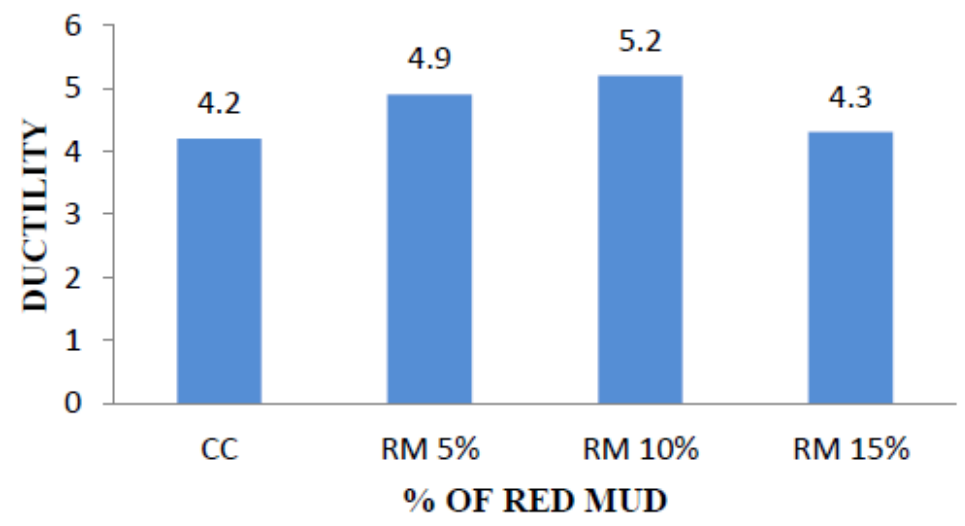

Figure 9: Ductility factor of Red Mud

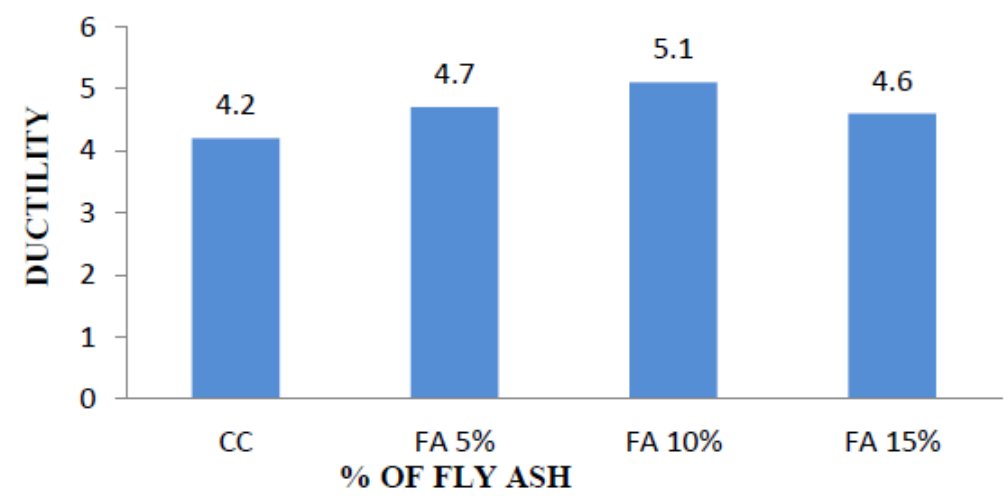

Figure 10:.Ductility factor of fly ash

\subsection{Microstructural Characterization}

The Microstructure and the morphology of the structure of redmud and fly ash were characterized with the help of scanning electron microscope (SEM). The images of the microstructures of Flyash and red mud were taken using secondary electron image mode under accelerating voltage of 20kV. The SEM images of the near spherical particles are taken from $(1 \mu \mathrm{m}-10 \mu \mathrm{m})$. Based on the capture image the fly ash and red mud yield different surface texture and grain sizes. In Fig.11a and Fig.11b, the considerable amounts of red mud particles are found. A little amount of unstructured phase was observed in Fig.11b. In fig.11c, the needle shaped particles were observed and Fig.11d is denser which fills the pore particles. Similarly Fig.12a and Fig.12b shows the fly ash particles. Fig.12c and Fig.12d shows the porous particles of the fly ash materials in an needle like shapes. 


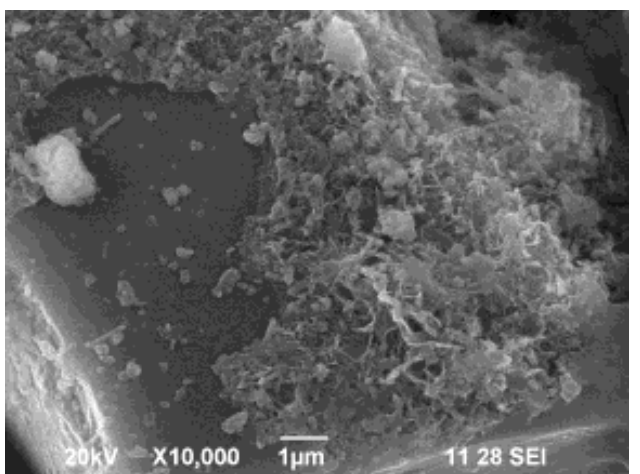

(a)

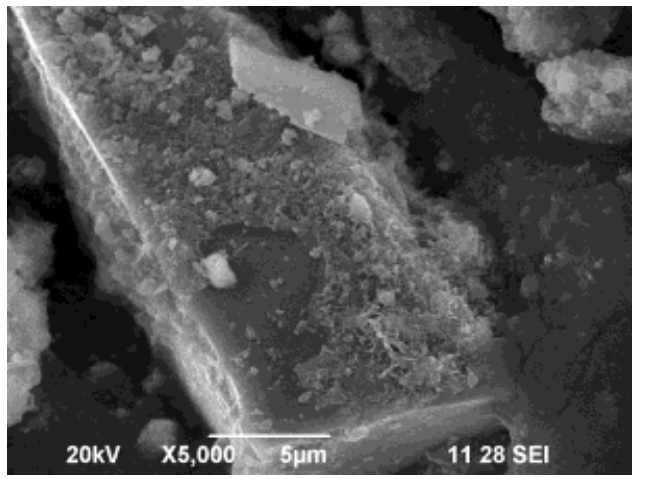

(c)

Figure 11: SEM Analysis of Beam Sample (Redmud)

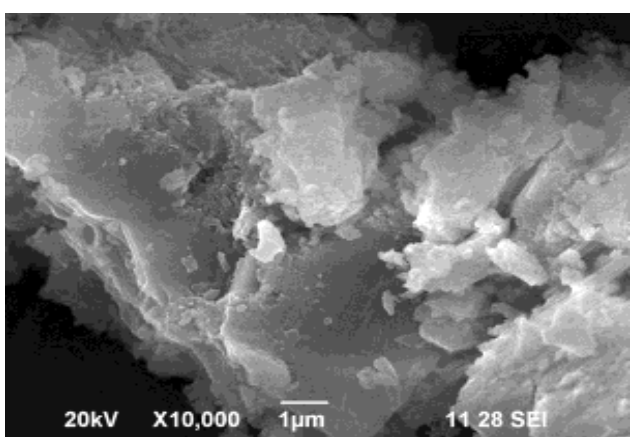

(a)

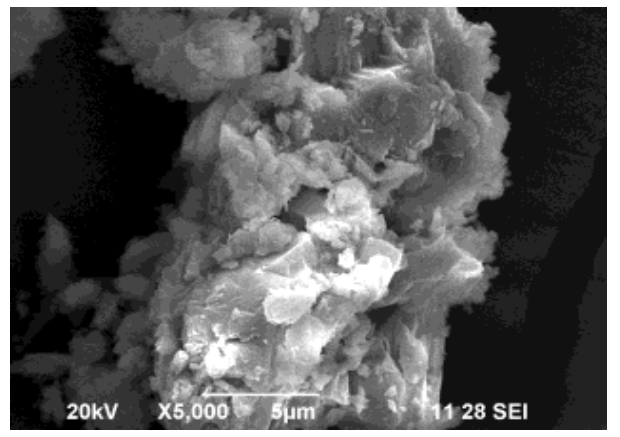

(c)

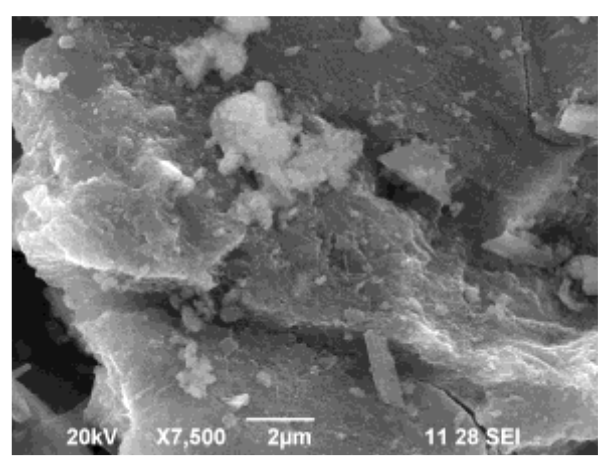

(b)

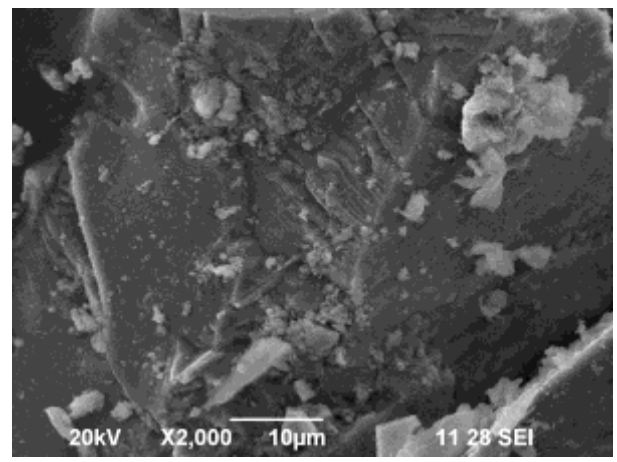

(d)

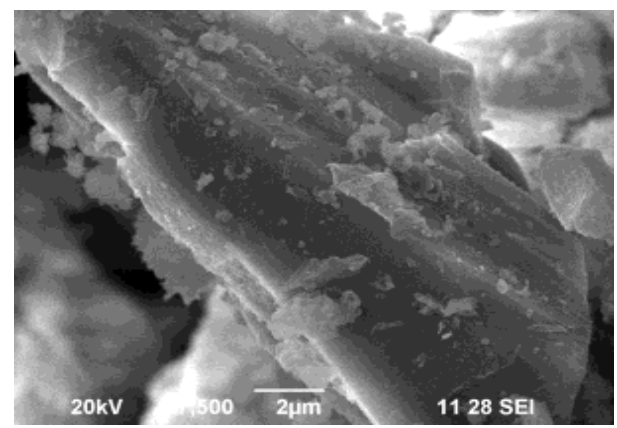

(b)

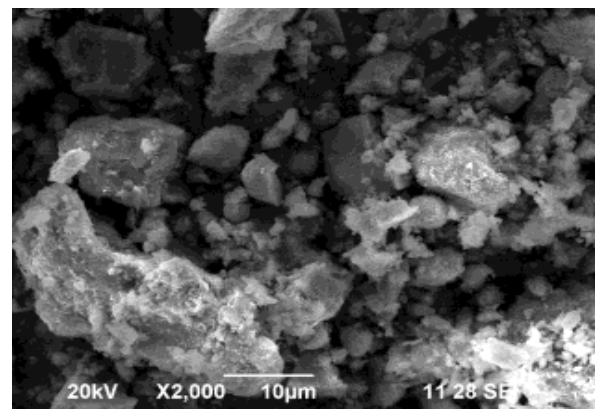

(d) 
Figure 12: SEM Analysis of Beam Sample (Fly Ash)

\section{CONCLUSIONS}

The present investigation is on functionally graded concrete with fly ash and red mud particles. Based on the experimental investigation the following conclusion are drawn,

$\checkmark$ Functionally grade concrete specimen of red has the compressive strength value of $35 \mathrm{~N} / \mathrm{mm}^{2}$ for $50 \mathrm{~mm}$ depth of FCG for the $10 \%$ addition of red mud. Whereas it is much higher than the other depths $(25 \mathrm{~mm}, 75 \mathrm{~mm})$ of FGCRM and conventional concrete. Similarly FGCFA has the increased in the compressive strength at the $50 \mathrm{~mm}$ depth for $10 \%$ of fly ash in concrete.

$\checkmark \quad$ The first crack load of the functionally graded concrete fly ash and red mud has 1.58 times more than the conventional beam.

$\checkmark$ From load-deflection curve it is found that the functionally graded concrete of red mud and fly ash is higher than the conventional beam.

$\checkmark \quad$ The microstructural characteristics shows that both the fly ash and red mud has the porous particles in the needle shapes which indicates the increases in the strength of the concrete.

\section{REFERENCES}

[1] LIMA, M.S.S., THIVES, L.P., HARITONOVS, V., BAJARS, K., "Red mud application in construction industry: review of benefits and possibilities", IOP Conference Series: Materials Science and Engineering, v. 251, pp. 012-033, 2017.

[2] VIJAYA, H.M., SAMUEL, T., WESLY, P.K., "Assessment of red mud as a construction material a review" Indian Journal of Scientific Research, v. 17, n. 2, pp. 473-478, 2018.

[3] DENTONI, V., GROSSO, B., MASSACCI, G., "Environmental sustainability of the alumina industry in Western Europe" Sustainability, v. 6, pp. 9477-9493, 2014.

[4] C.J. MOLINEUX, D.J. NEWPORT, B. AYATI, et al., "Bauxite residue (red mud) as a pulverised fuel ash substitute in the manufacture of lightweight aggregate" Journal of Cleaner Production, v. 112, n. 1, pp. 401-408, 2016.

[5] HOODA, A., MALIK, P., SANGWAN, V., “ Research paper on gauging engineering properties of red mud-fly ash-marble dust amalgamation". International Journal of All Research Education and Scientific Methods, v. 5, n.6, pp 252-258, 2016.

[6] YANG, J., ZHANG, D., HOU, J., et al., "Preparation of glass-ceramics from red mud in the aluminium industries" Ceramics International, v.34, n. 1, pp.125-130, 2008.

[7] DODOO-ARHIN, D., KONADU, D.S., ANNAN, et al., "Fabrication and characterisation of Ghanaian bauxite red mud-clay composite bricks for construction applications" American Journal of Materials Science, v. 3, n. 5, pp. 110-119, 2013.

[8] HE, J., ZHANG, J., YU, Y., et al., "The strength and microstructure of two geopolymers derived from metakaolin and red mud-fly ash admixture: a comparative study" Construction and Building Materials, v. 30, pp. 80-91, 2012.

[9] YANG, E.H., YANG, Y.Z., VICTOR LI, C., "Use of high volumes of fly ash to improve ECC mechanical properties and material greenness" ACI Materials Journal, v.104, n.6, pp. 620-628 303-310, 2007.

[10] LAM, L., WONG, Y.L., POON, C.S., "Degree of hydration and gel/space ratio of highvolume fly ash/cement systems" Cement Concrete Research, v. 30, n. 5, pp. 747-756, May. 2000.

[11] POON, C.S., LAM, L., WONG, Y.L., "A study on high strength concrete prepared with large volumes of low calcium fly ash", Cement Concrete Research, v. 30, n. 3, pp. 447-455, Mar. 2000.

[12] RAMEZANIANPOUR, A.A., MALHOTRA, V.M., "Effect of curing on the compressive strength, resistance to chloride-ion penetration and porosity of concretes incorporating slag, fly ash or silica fume", Cement Concrete Research, v. 17, n. 2, pp. 125-133, 1995.

[13] HAN AYLIE., BUNTARA STHENLY GAN., SHOLIHIN ASAD., et.al., "Parametric Study of the load carrying capacity of the functionally graded concrete of Flexural member" International journal of Engineering and Technology innovations. v. 5, n. 4, pp. 233-241, 2015.

[14] SATYANARAYANA, P., NATARAJAN, C., "Experimental Investigation of Functionally graded concrete with Fly ash" International journal of Earth Sciences and Engineering, v. 8, n. 2, pp. 143-148, 2015.

[15] KOIZUMI, M., "FGM Activities in Japan" Composites (Part.B) Engineering, v. 28, n.1- 2, pp. 1-4, 1997. 
[16] BAFEKRPOUR, E, SIMON, G.P., YANG, C., et al., "Fabrication characterization and modelling of functionally graded synthetic graphite/Polymer", NewYork, Nanocomposites: Synthesis, Characterization and Applications, 2013.

[17] LIQINGHUA., SHILANG XU., "Experimental investigation and analysis on flexural performance of functionally graded composite beam crack controlled by ultrahigh toughness cementitious composites" Science in China Series E: Technological Sciences, v. 52, n. 6, pp. 1648-1664, 2009.

[18] MOHAMMADI, S., ABDI, F., "Production Method of Rubber and Sulfur Fg Composites" Journal of Computational and Applied Research in Mechanical Engineering, v. 2, n. 1, pp. 63-69, 2012.

[19] SMITA SINGH, ASWATH, M.U., RANGANATHI, R.V., "Effect of mechanical activation of red mud on the strength of geopolymer binder" construction and building materials, v. 177, pp 91-101. Jul. 2018.

[20] BRUNORI, C., CREMISINI, C., MASSANISSO, P., "Reuse of a treated red mud bauxite waste: studies on environmental compatibility", Journal of Hazardous materials, v. 117, n. 1, pp. 55-63. 2005

[21] International Aluminium Institute, Bauxite Residue Management: Best Practices. 2015.

[22] SUTAR, H., MISHRA, S.C., SAHOO, S.K., et al., "Progress of red mud utilization: an overview" American Chemical Science Journal, v. 4, n. 3, pp. 255-279, 2014.

[23] XIAO-YONG WANG, KI-BANG PARK., "Analysis of Compressive strength development of concrete containing high volume fly ash" Construction and Building Materials, v..98, pp. 810-819, Nov. 2015.

\section{ORCID}

Sureshkumar Muthu Palaniappan Vennila Govindasamy

Abdul Bari Jabar
https://orcid.org/0000-0003-4485-991X

https://orcid.org/0000-0002-1947-1043

https://orcid.org/0000-0002-6502-296X 